\title{
Poligami dalam Perspektif Tafsir Modern Al-Manar
}

\author{
Madiha Dzakiyyah Chairunnisa \\ Institut Agama Islam Darussalam (IAID) Ciamis, Jawa Barat \\ Email: madihadzakiyyahchms@gmail.com \\ Hilman Purnama \\ Institut Agama Islam Darussalam (IAID) Ciamis, Jawa Barat \\ Ila Juanda \\ Institut Agama Islam Darussalam (IAID) Ciamis, Jawa Barat
}

\begin{abstract}
ABSTRAK
Menikah merupakan sunah nabi, meskipun hukum menikah sendiri bagi umat Islam ditentukan oleh tujuannya, menikah bisa menjadi wajib, sunah, mubah, bahkan haram pada dasarnya disesuaikan oleh niat manusia untuk menikah. Kompleksitas kehidupan manusia menimbulkan beberapa masalah dalam pernikahan. Diantaranya perdebatan soal poligami yang selama ini terjadi, telah menyita perhatian umat Islam, karena poligami dihubungkan dengan budaya Islam bahkan sunah nabi. Secara historis praktek poligami sudah ada sejak zaman pra-Islam. Banyak tokoh yang memberi pandangan tentang poligami dari berbagai aspek yang berkaitan dengan wanita.
\end{abstract}

\begin{abstract}
Married is the sunnah of the prophet, although the law of marriage alone for Muslims is determined by its purpose, marriage can be obligatory, sunnah, mubah, even haram is basically adjusted by human intention to get married. The complexity of human life raises several problems in marriage. Among them is the debate about polygamy that has happened so far, has seized the attention of Muslims, because polygamy is associated with Islamic culture even the sunnah of the prophet. Historically the practice of polygamy has existed since pre-Islamic times. Many figures gave views on polygamy from various aspects related to women.
\end{abstract}

Keywords: Polygamy, Ulama, Al-Manar Interpretation

\section{PENDAHULUAN}

Manusia sebagai makhluk ciptaan Allah SWT memiliki peranan dalam kehidupan, selain sebagai hamba, juga manusia sebagai khalifah. Peran 
sebagai hamba diwujudkan dengan ibadah dan mendekatkan diri dengan Allah SWT sebagai bentuk pengabdian. Sebagai khalifah, manusia juga memiliki cara untuk bertahan dan melanjutkan kehidupan dengan keturunan, bahkan menikah juga diasumsikan sebagai bentuk ibadah kepada Allah SWT.

Pernikahan secara etimologi adalah al-dhammu yang berarti menghimpunkan atau mengumpulkan (al-Husaini, t.t.:36). Menikah merupakan sunah nabi, meskipun hukum menikah sendiri bagi umat Islam ditentukan oleh tujuannya, menikah bisa menjadi wajib, sunah, mubah, bahkan haram pada dasarnya disesuaikan oleh niat manusia untuk menikah (Alhamdani, 1985:20). Kompleksitas kehidupan manusia menimbulkan beberapa masalah dalam pernikahan. Beberapa masalah yang ada dalam pernikahan tidak hanya disebabkan oleh faktor internal manusianya saja, akan tetapi tidak sedikit faktor eksternal juga mempengaruhi, di antara faktor eksternal yang berkembang di masyarakat adalah masalah yang ditimbulkan oleh gejala sosial. Antara lain pernikahan di bawah umur, nikah siri, dan poligami.

Masalah yang menjadi sasaran penelitian penulis adalah poligami. Perdebatan soal poligami yang selama ini terjadi, telah menyita perhatian umat Islam, karena poligami dihubungkan dengan budaya Islam bahkan sunah nabi. Secara historis praktek poligami sudah ada sejak zaman praIslam. Poligami dipraktekkan secara luas di kalangan masyarakat Yunani dan agama Kristen sebagaimana di dalam kitab Injil tidak ditemukan larangan Yesus melarang poligami tetapi setelah kekeristenan direvisi sesuai dengan doktrin Paulian yang memperkenalkan konsep monogami ke dalam filsafat Kristen maka praktek poligami berubah monogami (Philips dan Jones, 2005:14-15). Di Jazirah Arab sendiri sebelum Islam, masyarakat telah mempraktekan poligami, bahkan tidak ada jumlah tertentu mengenai banyaknya isteri (al-Kurdi, 1995:23).

Setelah Islam memberi kebebasan dan mengangkat derajat wanita dalam Islam, timbul pula berbagai sangkaan tentang kedudukan sebenarnya kaum wanita dan poligami dalam Islam. Sebenarnya tidak ada masalah baru dalam Islam, praktek poligami sesuai yang disampaikan di atas, sudah ada semenjak zaman pra-Islam. Tapi yang perlu diperhatikan adalah pembaruan jika sekarang ini poligami menjadi masalah kontemporer dalam Islam.

Banyak tokoh yang memberi pandangan tentang poligami dari berbagai aspek yang berkaitan dengan wanita. Pendapat hukum poligami secara garis besar dapat di bagi dalam tiga (3) kelompok, yaitu: Pertama, textualists, yang membolehkan poligami secara mutlak berdasarkan literal ayat bahwa Islam mengizinkan poligami dan membenarkan pendapatnya dengan mengacu pada praktek Nabi Muhammad SAW. Kedua, semitextualists, bahwa poligami hanya diperbolehkan dengan syarat-syarat dan dalam kondisi-kondisi tertentu. Ketiga, contextualists, percaya bahwa 
poligami dilarang dengan menafsirkan ayat secara komprehensif dan kontekstual (Nurmila, 2009:42-43).

Muhammad Abduh adalah seorang guru besar pada masanya. Ia sangat mencintai ajaran agamanya. Tapi ia memiliki kecenderungan menolak ajaran poligami meskipun pendapatnya bertentangan dengan tradisi lingkungannya pada saat itu. Padahal, ulama-ulama sebelumnya sepakat bahwa hukum asal poligami adalah mubah.

Berangkat dari pendapat Muhammad Abduh yang kontroversi dengan pendapat jumhur ulama dan ulama-ulama se-zamannya, maka menjadi sangat penting kiranya masalah ini diteliti lebih mendalam melalui skripsi ini, sebagai kontribusi dan kajian ulang pemikiran dalam pengembangan kajian yang bersifat kontemporer.

\section{KAJIAN TEORITIK}

\section{Konsep Poligami}

Poligami berasal dari bahasa Yunani yang terdiri dari kata 'poli' atau 'polus' yang berarti banyak, dan kata 'gamein' atau 'gamos' yang berarti kawin. Jadi secara bahasa poligami berarti suatu perkawinan yang banyak atau suatu perkawinan yang lebih dari seorang. Poligami dapat dibagi atas poliandri dan poligini. Poliandri adalah perkawinan seorang wanita dengan lebih dari seorang laki-laki sedangkan poligini adalah perkawinan seorang laki-laki dengan lebih dari seorang wanita. (Dewan Redaksi Ensiklopedi Islam, 1993: 107).

Pendapat lain mengatakan bahwa secara etimologis kata poligami berasal dari bahasa Yunani yang terdiri dari dua kata yaitu poli atau polus yang berarti banyak dan gamein atau gamos yang berarti perkawinan. Bila pengertian kata ini digabungkan maka poligami berarti suatu perkawinan yang banyak atau lebih dari seorang (Mursalin, 2007:15).

Sedangkan dalam istilah bahasa arab, poligami disebut juga yang diambil dari lafaz yang artinya terbilang atau banyak dan lafaz yang artinya istri-istri. (Warson, 1984: 205).

Praktek poligami yang bisa terjadi adalah seorang pria kawin dengan seorang wanita selayaknya monogami, setelah beberapa waktu suami tersebut kawin lagi tanpa menceraikan istri terdahulunya. Seandainya salah satu istri tersebut diceraikan dan jumlah istri masih lebih dari satu maka suami tersebut masih berpoligami. Apabila diceraikan dan tinggal satu istri saja maka itu disebut kembali monogami. (Soprapto, 1990: 73). berikut:

Adapun dasar hukum yang mengatur poligami adalah sebagai 


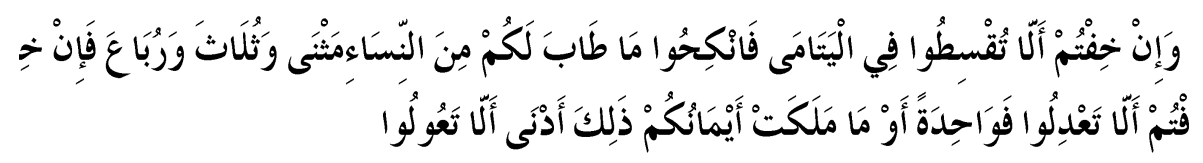

“Dan jika kamu takut tidak akan dapat berlaku adil terhadap (hakhak) perempuan yang yatim (bilamana kamu mengawininya), maka kawinilah wanita-wanita (lain) yang kamu senangi: dua, tiga atau empat. kemudian jika kamu takut tidak akan dapat berlaku adil, maka (kawinilah) seorang saja, atau budak-budak yang kamu miliki. Yang demikian itu adalah lebih dekat kepada tidak berbuat aniaya" (Q.S. alNisa, 4:3)

Ayat inilah yang menjadi sumber hukum atas terbukanya legitimasi poligami dalam sistem perkawinan yang merupakan satu-satunya ayat yang memberikan izin seorang laki-laki beristri lebih dari satu orang, ayat ini juga didukung oleh perilaku kerumah tanggaan Rasulullah SAW dan para sahabatnya.

Tapi, jika diperhatikan dengan seksama, ayat Alquran yang menjadi dasar hukum dibenarkannya poligami tersebut akan dimengerti, bahwa diperbolehkannya poligami itu bukanlah tujuan aslinya, melainkan hanyalah merupakan jawaban terhadap kondisi pada saat itu, dimana orang Arab telah biasa melakukannya (al-'Attar, 1976:106). Jadi, Alquran bukan membuat undang-undang pembolehan poligami, tetapi hanya membatasinya dengan beberapa ketentuan dan persyaratan tertentu.

Dalam Shahih Bukhari diriwayatkan bahwa Urwah bertanya kepada Aisyah, istri Rasulullah SAW tentang ayat tersebut, maka jawaban Aisyah, "wahai anak saudara perempuanku, yatim disini maksudnya adalah anak perempuan yatim yang ada di bawah asuhan walinya serta kecantikannya membuat pengasuh atau wali anak yatim tersebut senang kepadanya, kemudian ia ingin menjadikan perempuan ini sebagai istrinya, tetapi tidak memberikan mas kawin atau mahar kepadanya dengan adil, yaitu memberikan mahar yang sama dengan yang diberikan kepada perempuan yang lain. Karena itu pengasuh anak yatim dilarang mengawini mereka kecuali mau berlaku adil kepada mereka dan memberikan yang lebih tinggi dari biasanya. Kalau tidak dapat berlaku demikian maka lebih baik ia mengawini perempuan-perempuan lain yang ia senangi. (Bukhari, 1981: 116).

Melihat peristiwa disaat ayat tersebut diturunkan, maka dapat diambil kesimpulan bahwa masalah utamanya bukanlah mengenai persyaratan poligami, namun masalah anak yatim yang pada waktu itu kurang terjaga hak-haknya sebagai adat kebiasaan jahiliyah, dimana bangsa arab terbiasa melakukan poligami tanpa batas serta adanya motif mengawini perempuan yatim dengan maksud tertentu yang tidak dibenarkan syara. Kemudian kebiasaan buruk ini diarahkan oleh Allah. 
Dengan perkataan lain bahwa sesungguhnya pembolehan poligami dalam sistem perkawinan islam bukan tujuan asli atau tujuan utama dari ayat tersebut, tetapi hanya merupakan jawaban terhadap kondisi pada waktu itu. (Attar, 1976: 106).

\section{Syarat-syarat Poligami}

Dalam hukum islam syarat yang ditekankan adalah kemampuan untuk bersikap adil. Sebagaimana yang dijelaskan dalam Q.S. al-Nisa 4:3 khususnya lafaz . berdasarkan ayat ini jelas keadilan merupakan syarat mutlak yang sangat ditekankan. Barangsiapa yang merasa khawatir tidak dapat berlaku adil terhadap istri-istrinya maka hanya dapat diperbolekan memiliki satu orang istri saja. (Sibay, 1977: 137).

Jika memperhatikan realita yang ada, pada umumnya emosi dan kesukaan seorang suami tidaklah sama maka akan disadari bahwa perlakuan yang sama secara seragam terhadap setiap istri, malaksanakan keadilan dan berpaling dari diskriminasi adalah tugas yang paling sulit bagi seorang suami.

Karena itu Allah hanya memerintahkan agar manusia tidak condong kepada salah satu istri sehingga istri yang lain terkatung-katung tidak terurus nasibnya. Setidaknya, jangan sampai mengistimewakan yang satu sampai melupakan yang lain. Semua istri wajib diperlakukan dengan baik, bergaul dengan lembut, walaupun tidak begitu dicintai. Sehingga dengan perlakuan yang demikian itu diharapkan akan membaikan hati istrinya dan menimbulkan kasih sayang. (Sibay, 1977: 128).

Adil diwajibkan oleh Allah dalam hal makanan, minuman, pakaian, rumah, tempat tinggal maupun nafkah lahiriah dan bathiniah. Keadilan dalam hal-hal tersebut merupakan hak setiap istri tanpa membedakan istri yang satu dengan yang lainnya.

Demikian juga dalam hal tempat tinggal tidak boleh pilih kasih. Masing-masing istri harus dipisahkan antara satu dengan yang lainnya dalam rumah sendiri-sendiri, kecuali bila ada kerelaan dari seluruh pihak istri untuk tinggal serumah.

Pendapat Para Ulama Tentang Poligami

Dalam al-Quran hanya dua ayat yang secara tegas menerangkan tentang poligami yaitu Q.S. al-Nisa 4:3 dan 129. Meskipun menggunakan dalil yang sama, para ulama mempunyai kesimpulan yang berbeda-beda. Penyebabnya adalah pertama, perbedaan menggunakan istinbath dan dalildalil tambahan. Kedua, ada ulama yang menghubungkan penafsirannya dengan turunnya ayat, sementara yang lain tidak menghubungkannya. Ketiga, karena ada ulama yang disamping menggunakan sebab turunnya ayat juga mengaitkan dengan nash (teks) yang berhubungan dengan 
perkawinan. Keempat, sesuai dengan status al-Quran ada yang meyakini sebagai jawaban final dan sebagian lain meyakini bahwa al-Quran juga sebagai jawaban final yang penafsirannya harus sesuai dengan perkembangan dan tuntutan zaman.

Selama sekitar 1300 tahun para ulama tidak pernah berbeda pendapat dalam hukum poligami (ta'addud al-zawjat). Hingga abad ke-18 M (ke-13 H) tidak ada pro kontra mengenai bolehnya poligami, dan semuanya sepakat bahwa poligami itu mubah (boleh). Sebab kebolehannya telah didasarkan pada dalil yang qath'i (pasti) (Lu'bah, 2005:306)

Dalam penafsiran ayat-ayat poligami, para ulama diklasifikasikan pada tiga kelompok. Pertama, golongan yang berpandangan bahwa islam menganjurkan poligami. Kedua, golongan yang berpendapat bahwa islam membolehkan poligami dengan syarat-syarat dan kondisi tertentu yang sangat terbatas. Ketiga, golongan yang berpandangan bahwa islam menganut prinsip monogami.

1) Poligami Boleh Secara Mutlak

Pendapat ini dipegang oleh mayoritas ulama klasik dari abad pertengahan. Mereka yang membolehkan seorang suami berpoligami maksimal dengan 4 istri dengan syarat mampu berlaku adil secara materi dan tidak khawatir berbuat zalim serta mempunyai nafkah yang cukup bagi istri dan anak-anaknya.

Para imam yang empat, yakni Imam Abu Hanifah, Imam Malik, Imam Syafi'i, dan Imam Ahmad, rahimahumullah, sepakat bahwa poligami itu mubah. Hal ini dapat kita lihat pendapat mereka dalam kitab "al-Fiqh 'Ala Al-Madzahib Al-Arba'ah", pada pembahasan pembagian nafkah dan bermalam kepada para istri (Al-Jaziry 1996:206-217)

Demikian juga bisa kita lihat, dalam pembahasan sebelumnya pendapat ulama terutama para (mufassir), baik Thabari ataupun Ar-Razi, bahwa poligami adalah dibolehkan selama bisa berlaku adil. Sedangkan ulama yang lain yaitu Al-Jashshash yang juga intensif mengupas poligami, menurut Jashshash bahwa poligami bersifat boleh (mubah). Kebolehan ini juga disertai dengan syarat kemampuan berbuat adil diantara para istri, termasuk material, seperti tempat tinggal, pemberian nafkah, pakaian dan sejenisnya. Kedua kebutuhan non material, seperti rasa kasih sayang, kecendrungan hati dan semacamnya. Namun dia memberikan catatan, bahwa kemampuan berbuat adil di bidang non material ini amat berat.(AlJashshash, tt:50).

Para ilmuan klasik (fuqaha) berpendapat, bahwa Allah mengizinkan menikahi empat wanita. Menurut mereka, walaupun kebolehan di sini ditambah dengan kondisi yang tidak mungkin ditunaikan, keadilan dalam kasih sayang, perasaan, cinta dan semacamnya, namun, selama kemampuan 
berbuat adil di bidang nafkah dan akomodasi bisa ditunaikan, izin untuk berpoligami menjadi sesuatu yang bisa diperoleh. Alasan yang mereka kemukakan untuk mendudung ide ini adalah, bahwa nabi sendiri pernah berkata hubungannya dengan ketidakmampuannya berbuat adil dalam hal kebutuhan batin (Khoiruddin, 1996:99).

2) Poligami Boleh dengan Alasan dan Kondisi Tertentu

Pendapat ini pada umumnya dipegang oleh ulama kontemporer seperti Muhammad Abduh, Muhammad Syahrur, al-Maraghi, Quraish Shihab, Fazrur Rahman dan Sayyid Qutub. Menurut Muhammad Abduh, sebagaimana dikutip oleh Khoiruddin Nasution, islam memang membolehkan poligami, tetapi suami dituntut harus mampu berlaku adil kepada para istri. Syarat ini menurut Muhammad Abduh, dapat dirinci menjadi tiga kondisi. Pertama, kebolehan untuk poligami sesuai dengan kondisi tertentu dan tuntutan zaman, seperti kemampuan istri untuk melahirkan keturunan. Kedua, syarat dapat berlaku adil merupakan syarat yang sangat berat, khususnya dalam pembagian cinta dan hal-hal yang berhubungan dengan pelayanan batin. Di sini tidak disebutkan konsep keadilan itu harus adil yang berkenaan dengan cinta, karena dikhawatirkan ketidakadilan dalam hal cinta menyebabkan ketidakadilan dalam pembagian materi. Ketiga, bahwa suami yang tidak dapat melaksanakan syarat adil untuk berpoligami, hanya boleh melakukan monogami. Melihat betapa beratnya melakukan syarat adil, Muhammad Abduh menyimpulkan bahwa prinsip perkawinan dalam islam adalah monogami.

Meskipun pada prinsipnya Muhammad Abduh melarang poligami, tetapi tetap membolehkan dalam kondisi-kondisi yang sangat mendesak (darurat), seperti istri mandul. Sebaliknya ia sangat mencela poligami yang bertujuan untuk memuaskan hawa nafsu birahi. Ia memang mengakui poligami di zaman Rasulullah SAW karena kondisi yang menghendaki demikian. Pada waktu itu wanita lebih banyak dari laki-laki dan poligami ditujukan untuk menjaga wanita. Menurut Muhammad Abduh, konteks sejarah turunnya ayat-ayat poligami harus dibaca cermat dan jernih. (Nasution, 1996: 102-104). Kondisi di awal islam telah jauh berbeda dengan kondisi sekarang. Jika poligami pada saat itu lebih banyak membawa manfaat, maka kondisi saat ini lebih banyak membawa mafsadat.

Sayyid Qutub berpendapat bahwa poligami merupakan suatu perbuatan rukhsah. Karena merupakan rukhsah, maka bisa dilakukan hanya dalam keadaan darurat, yang benar-benar mendesak. Kebolehan ini pun masih disyaratkan bisa berbuat adil terhadap istri-istri. Keadilan yang dituntut disini termasuk dalam bidang nafkah, mu'amalat, pergaulan, serta pembagian malam. Sedang bagi calon suami yang tidak bisa berbuat adil, maka diharuskan cukup satu saja (Sayyid Qutub, 1961:236) 
Imam al-Maraghi dalam tafsir al-Maraghi menjelaskan bahwa diperbolehkannya poligami dalam Q.S. al-Nisa 4:3 tersebut dipersulit dan diperketat syarat kebolehannya. Menurut Imam al-Maraghi, poligami adalah suatu keadaan darurat yang hanya diperbolehkan bagi orang-orang yang benar-benar membutuhkannya dengan syarat dapat dipercaya menegakkan keadilan dan tidak melakukan perbuatan yang melanggar batas. (al-Maraghi, 1993: 325).

Imam al-Maraghi mengatakan bahwa prinsip ideal rumah tangga adalah monogami, tapi dalam kondisi tertentu seorang suami bisa berpoligami. Situasi-situasi yang memperbolehkan seorang laki-laki boleh melakukan poligami menurut imam al-Maraghi adalah:

1) Istrinya mandul dan ia menginginkan anak

2) Istri sudah tua (tidak haid) atau monoupouse dan ia mengharapkan anak

3) Tidak cukup mempunyai seorang istri demi menjaga kehormatan diri dari berbuat zina

4) Bila hasil sensus, kaum wanita lebih banyak dari kaum pria dalam suatu negara dengan perbedaan mencolok

5) Walaupun demikian seorang laki-laki yang melakukan poligami harus mampu berbuat adil kepada seluruh istri-istrinya.

Sementara Sayyid Qutub mengemukakan bahwa islam tidaklah menumbuhkan ajaran $\mathrm{p}$ oligami, tapi hanya membatasinya dan tidak menyuruh melakukannya, tapi hanya sebuah rukhsah yang terbatas. Menurutnya poligami hanya boleh dilakukan jika dalam keadaan yang benar-benar mendesak serta dapat berbuat adil kepada para istri. Sehingga jika seorang laki-laki tidak memenuhi syarat dan kondisi tersebut, maka hilanglah rukhsahnya untuk melakukan poligami, artinya suami hanya boleh mempunyai satu istri saja. (Qutub, 1971: 243).

Quraish Shihab mengatakan bahwa poligami merupakan pintu darurat kecil yang hanya dilalui dalam kondisi amat diperlukan dengan syarat yang tidak ringan. Menurutnya, Q.S. al-Nisa 4:3 tidaklah membuat suatu peraturan tentang poligami karena poligami telah dikenal dan dilaksanakan oleh syariat agama dan adat istiadat sebelum islam. Ayat ini juga tidak mewajibkan poligami atau menganjurkannya, ayat ini hanya berbicara tentang bolehnya poligami dan itupun merupakan pintu darurat kecil, yang hanya dilalui saat amat diperlukan dan dengan syarat yang tidak ringan. (Shihab, 1999:200).

Quraish Shihab menegaskan, pembahasan poligami dalam al-Quran hendaknya tidak ditinjau dari segi ideal atau buruknya, tapi harus dilihat dari sudut pandang pengaturan hukum, dalam aneka situasi dan kondisi yang mungkin terjadi. Dicontohkan dengan kemungkinan mandulnya dan 
terjangkitnya penyakit parah seorang istri merupakan suatu kemungkinan yang tidak aneh. (Shihab, 1999: 200).

Adapun keadilan yang disayaratkan dalam Q.S. al-Nisa 4:3, menurut Quraish Shihab adalah keadilan dalam hal materi, sedangkan Q.S. al-Nisa 4:129 adalah keadilan dalam bidang immaterial (cinta). Itu sebabnya hati yang berpoligami dilarang memperturutkan hatinya dan berlebihan dalam kecenderungan kepada yang dicintai. Dengan demikian tidaklah tepat menjadikan ayat ini sebagai dalil untuk menutup pintu poligami serapatrapatnya.

Menurut Fazlur Rahman, asas ideal perkawinan dalam islam adalah monogami. Kebolehan poligami merupakan cara al-Quran merespon masalah yang ada dan sekaligus melakukan pembaruan dengan jalan bertahap. Ia mencatat bahwa suami istri adalah pasangan yang saling mencintai dan memberi kasih sayang. Ikatan perkawinan pada dasarnya tidak hanya dibatasi pada pelayanan yang bersifat material semata, tetapi juga yang bersifat non material (cinta). Dikhawatirkan ketidakadilan dalam hal non material akan mempengaruhi pelayanan dalam bidang material. AlQuran telah menyatakan bahwa manusia tidak dapat berlaku adil terhadap para istrinya, sama artinya dengan menyatakan bahwa tidak mungkin seorang laki-laki mencintai lebih dari seorang wanita sebagai istri. (Nasution, 2002: 16).

3) Poligami Dilarang

Dengan melihat ayat-ayat al-Quran secara komprehensif, kelompok yang melarang poligami mengatakan bahwa poligami tidak dibolehkan. Diantara ulama yang melarang poligami adalah al-Thahir al-Haddad, seorang ulama berkebangsaan Tunisia, ketika memahami ayat-ayat tentang poligami, ia menghubungkan dengan ayat-ayat tentang perkawinan, tujuan perkawinan adalah untuk menciptakan keluarga yang bahagia, tenteram dan sejahtera. Sementara dalam poligami sangat sulit menciptakan keluarga yang harmonis antara suami, istri dan anak-anak apalagi harta kekayaan peninggalan suami ketika meninggal sangat sedikit dan terbatas. Adapun poligami yang dipraktekan oleh Rasulullah SAW adalah kekhususan bagi dirinya dan bukan merupakan tasyri bagi umatnya. (Haddad, 1993: 77).

Pemikiran al-Thahir al-Haddad sejalan dengan perundang-undangan perkawinan negerinya yang melarang poligami secara mutlak dan menghukum bagi yang melanggar. Seorang yang melakukan poligami sebelum perkawinannya bubar (cerai) akan disangsi dengan hukuman penjara selama setahun dan membayar denda 240.000 frank atau salah satu dari dua hukuman tersebut. (Atthar, 1976: 266). Alasan yang dikemukakan oleh mereka untuk melarang poligami adalah al-Quran yang menuntut adanya kesanggupan berlaku adil, sementara mustahil seorang suami dapat 
berlaku adil terhadap istri-istrinya, padahal adil adalah syarat mutlak kebolehan poligami. (Nasution, 1996: 106)

\section{Konsep Tafsir}

Secara harfiah (etimologis), tafsir berarti menjelaskan (al-idhah), menerangkan (al-tibyan), menampakkan (al-izhar), menyibak (al-kasyf), dan merinci (al-tafshil). Kata tafsir terambil dari kata al-fasr yang berarti alibanah dan al-kasyf yang keduanya bermakana membuka (sesuatu) yang tertutup (kasyf al mugaththa). Sebagian ulama yang lain menyatakan bahwa kata tafsir terambil dari kata at-tafsirah, dan bukan dari kata al-fasr yang berarti "sebutan bagi sedikit air yang digunakan oleh seorang dokter untuk mendiagnosis penyakit pasien." Bila seorang dokter dengan sedikit air bisa mendiagnosis penyakit pasien, dengan tafsir seorang mufassir mampu menyibak isi kandungan ayat al-Quran dari berbagai aspeknya. (Izzan, 2011:4-5)

Masih menurut Ahmad Izzan, bahwa pada dasarnya tafsir adalah rangkaian penjelasan dari pembicaraan atau teks al-Quran atau tafsir adalah penjelasan lebih lanjut tentang ayat-ayat al-Quran yang dilakukan oleh seorang mufassir. Tafsir merupakan keterangan atau penjelasan tentang alQuran. (Izzan, 2011:6)

\section{Mazhab Tafsir}

Secara garis besar ada tiga macam mazhab tafsir yakni tafsir bi alriwayah/bi al-manqul/bi al-matsur, tafsir bi al-rayi/bi al-dirayah/bi alijtihad/bi al-istinbath dan tafsir bi al-isyarah/al-bathiniyah.

Tafsir bi al-riwayah menafsirkan al-Quran dengan al-Quran, menafsirkan al-Quran dengan al-hadits atau manfsirkan al-Quran dengan menukilkan pendapat para sahabat bahkan tabiin menurut sebagian ahli tafsir. (Tafsir bi al-rayi menafsirkan al-Quran dengan kekuatan rayi (pemikiran) yang didasarkan pada pendekatan kebahasaan. Tafsir bi alisyarah adalah tafsir al-Quran yang dilakukan dengan lebih mengutamakan makna-makna al-Quran yang tersurat daripada yang tersirat. (Izzan, 2011: 93).

\section{1) Mazhab Tafsir bi al-Riwayah}

Mazhab tafsir bi al-riwayah sering juga disebut sebagai mazhab bi al-matsur atau bi al-manqul. Kata al-matsur bentuk isim maful (objek) dari kata atsara-ya'tsiru-atsran yang secara etimologis berarti menyebutkan atau mengutip (naqala) dan memuliakan atau menghormati (akrama). Al-atsar juga bisa berarti sunnah, hadis, jejak, bekas, pengaruh, dan kesan. Jadi katakata al-matsur, al-naql, al-manqul, dan al-riwayah pada hakitkatnya, mengacu pada makna yang sama yaitu mengikuti atau mengalihkan sesuatu yang sudah ada dari orang lain atau masa lalu. Jadi tafsir bi al-riwayah yang dikenal juga dengan tafsir bi al-matsur, tafsir bi al-manqul ialah corak 
penafsiran ayat al-Quran dengan ayat al-Quran yang lain, ayat al-Quran dengan sunnah nabawiyah, ayat al-Quran dengan pendapat para sahabat dan (tabiin menurut sebagian pendapat ulama). (Izzan, 2011:57)

Contoh tafsir ayat al-Quran dengan ayat al-Quran yang lain:

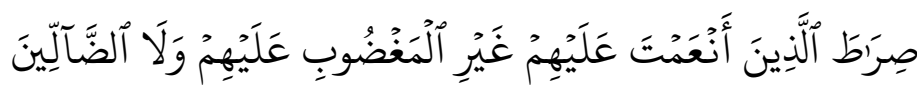

(yaitu) jalan orang-orang yang telah Engkau beri nikmat kepada mereka; bukan (jalan) mereka yang dimurkai dan bukan (pula jalan) mereka yang sesat.(Q.S. Al-Fatihah, 1:7)

Ayat tersebut menafsirkan ayat sebelumnya yaitu ihdinash shiratal mustaqim, tunjukilah kami jalan yang lurus (Q.S al-Fatihah 1:6).

Contoh tafsir ayat al-Quran dengan sunnah nabawiyah diantaranya Nabi Muhammad SAW menafsirkan kata zulmun (kegelapan) dengan kata syirik (penyekutuan Allah SWT) ketika menafsirkan ayat berikut:

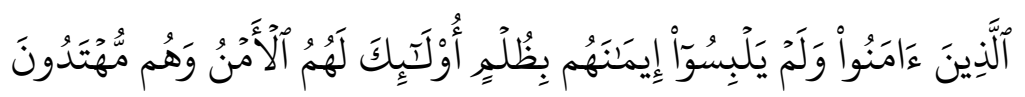

“Orang-orang yang beriman dan tidak mencampuradukkan iman mereka dengan kezaliman (syirik), mereka Itulah yang mendapat keamanan dan mereka itu adalah orang-orang yang mendapat petunjuk." (Q.S. al-Anam 6:82).

Dalam sebuah riwayat dikatakan bahwa seorang musyrik telah menyerang seorang muslim dan kemudian membunuhnya. Kemudian ia pun menyerang muslim lainnya dan membunuhnya. Sesudah itu musyrik tersebut bertanya kepada Nabi Muhammad SAW apakah islamnya akan diterima jika ia memeluk islam setelah bergelimangan dosa atas apa yang ia lakukan. Nabi Muhammad SAW menjawab bahwa ia akan diterima tobatnya selama tobatnya dilakukan dengan sungguh-sungguh, dan memperjuangkan islam sebagaimana ia ingin menghancurkannya. Lalu ia memecut kudanya dengan cepat untuk menyerbu pihak musuh islam seraya ia membunuh beberapa orang hingga akhirnya dia sendiri terbunuh. Menurut Bakr bin Sadawah, para sahabat menganggap ayat di atas (Q.S alAnam 6: 82) berkenaan dengan peristiwa orang di atas yang menegaskan bahwa iman seseorang yang tidak dicampuri syirik keamanannya dijamin oleh Allah SWT.

Para sahabat merasa berkecil hati atas turunnya ayat ini (Q.S. alAnam 6: 82). Lalu nabi Muhammad SAW menjelaskan bahwa yang dimaksud zulmun pada ayat diatas adalah syirik seraya merujuk Q.S. Luqman 31: 13. (Izzan, 2011: 63-65)

2) Mazhab Tafsir bi al-Dirayah 
Kata dirayah berakar dari kata dara-yadri-daryan-dirayatan yang artinya mengetahui atau memahami. Kata dirayah merupakan sinonim dari kata rayun yang artinya melihat, mengerti, menyangka mengira, meduga. Kata rayu juga bisa diartikan dengan al-itiqad, akal pikiran, ijtihad, qiyas (analogi). Tafsir dirayah dinamakan jiga tafsir bi al-maqul, bi al-rayi, dan bi al-ijtihad sebagaimana para pengikut ahl al-rayi dalam dunia fikih yang dikenal dengan sebutan ashhab al-qiyas. Tafsir bi al-rayi adalah penafsiran al-Quran berdasarkan ijtihad para mufassir setelah mengenal lebih dahulu lafal-lafal bahasa arab dan argumentasi-argumentasinya yang dibantu oleh penggunaan syair-syair jahili dan mempertimbangkan asbab al-nuzul dan sarana lainnya yang dibutuhkan oleh para mufassir. Intinya tafsir bi al-Rayi adalah penafsiran al-Quran yang mengutamakan pendekatan kebahasaan dan berbagai seginya yang sangat luas. (Izzan, 2011:72)

Para ahli tafsir membagi tafsir bi al-rayi menjadi dua jenis yaitu tafsir bi al-rayi yang mahmud (terpuji) dan tafsir bi al-rayi yang madzmum (tercela). Jenis panafsiran tafsir bi al-rayi bisa dikataka terpuji jika ia memiliki ciri-ciri; sesuai dengan tujuan pembuat syariat (Allah SWT); jauh dan terhindar dari kesalahan dan kesesatan; dibangun atas dasar-dasar kaidah kebahasaan yang tepat dengan mepraktekkan gaya bahasa (uslub) dalam memahami nash al-Quran; dan tidak mengabaikan kaidah-kaidah penafsiran yang sangat penting seperti asbab al-nuzul dan ilmu munasabah. Tafsir bi al-rayi inilah yang tergolong tafsir yang sangat baik, terpuji, dan layak digunakan. (Izzan, 2011:72-73).

Sebaliknya tafsir yang tercela yaitu tafsir yang memiliki ciri-ciri; mufassir tidak mempunyai keilmuan yang memadai; tidak didasarkan pada kaidah-kaidah keilmuan; menafsirkan al-Quran dengan semata-mata mengandalkan kecenderungan hawa nafsu; serta mengabaikan aturanaturan bahasa arab dan syariah yang karenanya penafsirannya menjadi rusak dan sesat. (Izzan, 2011:73).

3) Mazhab Tafsir bi al-isyarah

Kata al-isyarah merupakan bentuk sinonim (muradif) dari kata aldalil yang berarti tanda, petunjuk, indikasi, isyarat, sinyal perintah, panggilan, nasihat dan saran. Jadi tafsir bi al-isyarah adalah penakwilan alQuran dengan mengesampingkan (makna) lahiriah karena ada indikator (isyarat) tersembunyi yang hanya bisa disimak oleh orang-orang yang memiliki ilmu suluk dan tasawuf. (Izzan, 2011:88).

Berdasarkan isi dan substansinya, tafsir bi al-isyarah dapat dibedakan dalam dua macam: tafsir bi al-isyarah al-maqbul dan tafsir bi alisyarah al-mardud. Syarat-syarat tafsir bi al-isyarah al-maqbul yaitu; tidak menafikan makna lahir dan makna-makna yang terkandung dalam redaksi al-Quran; mufassirnya tidak mengklaim bahwa itulah satu-satunya penafsiran yang benar tanpa mempertimbangkan makna tersurat; tidak 
menggunakan takwil yang jauh menyimpang dan penakwilannya lemah; tidak bertentangan dengan dalil syariat dan argumentasi aqli; serta adanya pendukung dalil-dalil syariat yang memperkuat penafsirannya. (Izzan, 2011:89).

\section{Metode Tafsir}

Kata metode berasal dari bahasa Yunani, methodos, yang berarti jalan atau cara. Dalam bahasa inggris, method, sedangkan dalam bahasa arab thariqat dan manhaj. Dalam bahasa Indonesia, kata tersebut mengandung arti ,"cara yang teratur dan terpikir baik-baik untuk mencapai maksud, cara kerja yang konsisten untuk memudahkan pelaksanaan suatu kegiatan guna mencapai sesuatu yang ditentukan. (Izzan, 2011:97)

Metode tafsir merupakan cara-cara penafsiran al-Quran, cara yang teratur dan terpikir baik-baik untuk mencapai pemahaman yang benar tentang apa yang dimaksud Allah SWT dalam ayat-ayat al-Quran yang diturunkan kepada Nabi Muhammad SAW. Metode tafsir berisi seperangkat kaidah dan aturan yang harus ditaati ketika menafsirkan alQuran. Sedangkan metodologi tafsir adalah ilmu tentang cara penafsiran alQuran. (Izzan, 2011:98).

Abd al-Hayy al-Farmawi menyebutkan ada empat jenis metode penafsiran al-Quran yaitu:

1) Metode Tahlili

Secara harfiah, al-tahlili berarti terlepas atau terurai. Jadi tafsir tahlili ialah metode penafsiran ayat-ayat al-Quran melalui pendekskripsian (menguraikan) makna yang terkandung dalam ayat-ayat al-Quran dengan mengikuti tata tertin susunan atau urut-urutan surat-surat dan ayat-ayat alQuran yang sedikit banyak analisis tentang kandungan ayat itu. (Izzan, 2011:103).

Tafsir al-Tahlili memiliki kelebihan yang sangat khas dibandingkan tafsir yang menggunakan metode lainnya. Kelebihan tafsir al-tahlili antara lain, keluasan dan keutuhannya dalam memahami al-Quran. Melalui metode tahlili, seseorang diajak serta untuk memahami al-Quran dari Q.S. al-Fatihah hingga Q.S. al-Nas atau ia diajak serta untuk memahami ayat dan surat dalam al-Quran secara utuh dan menyeluruh. Cara memahami alQuran secara tartil seperti inilah yang dilakukan para sahabat. Metode ini terkesan memunculkan sikap yang sangat hati-hati dan penuh tanggung jawab dalam memhamai pesan moral al-Quran. Metode tahlili juga menyajikan pembahasan al-Quran yang sangat luas yang meliputi berbagai aspek, seperti kebahasaan, sejarah dan hukum. (Izzan, 2011:105).

Sebagai sebuah metode yang bersifat nisbi karena hasil karya manusia, metode tafsir al-tahlili tidak bisa terlepas dari kelemahan, antara 
lain, kajian metode tafsir tahlili kurang mendalam, tidak detil, dan tidak tuntas dalam pembajasan dan penyelesaian topik-topik yang dibicarakan. Penafsiran al-Quran dengan metode tahlili memerlukan waktu yang panjang dan menuntut ketekunan kesabaran yang tinggi. Di sisi lain, jalan metode tahlili pun tidak sistematis seperti yang dikritik oleh Rasyid Ridha. (Izzan, 2011:105).

2) Metode ijmali

Secara bahasa, kata al-ijmali berarti ringkasan, ikhtisar, global dan penjumlah. Jadi tafsir al-ijmali ialah penafsiran al-Quran dengan cara mengemukakan isi dan kandungan al-Quran melalui pembahasan yang panjang dan luas, tidak secara rinci. Pembahasan tafsir al-ijmali hanya meliputi beberapa aspek dan dalam bahasa yang sangat singkat. Misalnya Tafsir al-Farid li al-Quran al-Majid hanya mengedepankan arti kata-kata, sabab nuzul, dan penjelasan singkatnya. Adakalanya juga mengedepankan al-mufradat, lalu sabab nuzul dan al-mana atau mendahulukan makna dan sabab nuzul. (Izzan, 2011:105).

3) Metode al-Muqarran

Tafsir al-muqarran ialah tafsir yang menggunakan pendekatan perbandingan antara ayat-ayat al-Quran yang redaksinya berbeda padahal isi kandungannya sama, atau antara ayat-ayat yang redaksinya mirip padahal isi kandungannya berlainan. Metode komparasi ialah menafsirkan ayat-ayat al-Quran yang selintas tampak berlawanan dengan hadis padahal sebenarnya sama sekali tidak bertentangan. (Izzan, 2011:106).

4) Metode Maudhui

Menurut Dr. Musthafa Muslim tasir al-Maudhui ialah tafsir yang membahas tentang masalah-masalah al-Quran yang memiliki kesatuan makna atau tujuan dengan cara menghimpun ayat-ayatnya yang bisa juga disebut tafsir tauhidi (kesatuan) untuk kemudian melakukan penalaran (analisis) terhadap isi kandungannya menurut cara-cara tertentu dan berdasarkan syarat-syarat tertentu untuk menjelaskan makna-maknanya dan unsur-unsurnya, serta menghubung-hubungkan antara yang satu dan lainnya dengan kolerasi yang bersifat komprehensif. (Izzan, 2011:114).

Kaidah Tafsir

Kaidah tafsir terdiri dari dua kata yakni kaidah dan tafsir. Dalam bahasa arab, kaidah yaitu qoidah berarti dasar, asas, panduan, prinsip, peraturan, model, contoh dan cara. Qoidah dalam istilah para ahli tafsir ialah hukum (aturan) yang bersifat menyeluruh atau umum (kulli) yang dengan aturan-aturan umum itu bisa dikenali (dideteksi) hukum-hukum yang partikular (juzi). Jadi kaidah tafsir menurut Khalid Utsman al-Sabt adalah rangkaian aturang yang bersifat umum (global) yang mengantarkan (menuntun) seseorang (mufassir) untuk mengistinbatkan (menggali) makna- 
makna al-Quran dan mengenali cara memperoleh atau menghasilkan pemahamannya.

Adapun kaidah-kaidah tersebut adalah menafsirkan al-Quran dengan al-Quran; menafsirkan al-Quran dengan sunnah; menafsirkan al-Quran dengan pendapat para sahabat; pendekatan kebahasaan; dan penafsiran berdasarkan kesesuaian makna teks.

\section{METODE PENELITIAN}

Metode yang digunakan dalam penelitian ini adalah metode penelitian deskriptif, yaitu suatu metode penelitian yang bertujuan untuk melukiskan secara sistematis fakta atau karakteristik populasi tertentu atau bidang tertentu secara faktual dan cermat. Menurut Subana menyatakan bahwa "penelitian deskriptif adalah penelitian yang tidak hanya sampai kepada pengumpulan dan penyusunan data-data tetapi meliputi penafsiran analisa terhadap data yang dipakai" (Subana, 2001: 26). Dengan metode ini penulis mendeskripsikan isi Tafsir al-Manar, khususnya surat an-Nisa' ayat 3 mengenai pandangan Abduh tentang poligami. Kemudian hasil dari deskripsi tersebut dianalisis agar diperoleh suatu kejelasan mengenai pandangan Abduh tentang poligami.

\section{HASIL PENELITIAN DAN PEMBAHASAN}

Biografi Muhammad Abduh

Lengkapnya bernama Muhammad Abduh bin Hassan Khair Ullah (Lahir di Desa Mahallat Nashr, Provinsi Gharbiyah, Mesir, pada 1265 H/1849 M). Ayahnya bernama Abduh Khair Allah, warga Mesir keturunan Turki. Sedangkan ibunya adalah perempuan dari suku Arab yang nasabnya sampai kepada Umar bin Khattab, sahabat Nabi Muhammad SAW. (Mohammad, 2006:225).

Sebagaimana umumnya keluarga islam, pendidikan agama pertama didapat dari lingkungan keluarga. Adalah sang ayah, Abduh Khair Allah, yang menyentuh Muhammad Abduh di arena pendidikan. Ayahnya mengajarkan baca tulis, dan menghafal al-Quran. Allah memberikan kecerdasan kepada Muhammad Abduh. Ini terbukti hanya dalam tempo kurang dari tiga tahun mempelajari al-Quran, ia sudah mampu menghafal semua isinya. (Mohammad, 2006:225-226).

Setelah belajar dari ayahnya, di usia 14 tahun Muhammad Abduh dikirim ke Thanta, di sebuah lembaga pendidikan masjid al-Ahmad, milik al-Azhar. Di sini ia belajar bahasa arab, al-Quran dan fikih. Dua tahun belajar di sini, Muhammad Abduh sudah merasa bosan. Ini karena menurut 
Muhammad Abduh sistem pendidikannya hanya mengandalkan hafalan dan tidak memberi kebebasan kepada muridnya untuk mengembangkan pikirannya. Maka iapun undur diri dan pulang ke Mahallat Nashr. (Mohammad, 2006:226).

Di usia 17 tahun, tepatnya tahun $1866 \mathrm{M}$, Muhammad Abduh menikah. Tapi ayahnya tak rela jika Muhammad Abduh berhenti menuntut ilmu. Maka, 40 hari setelah menikah, Muhammad Abduh diminta kembali oleh ayahnya untuk kembali ke Thanta. Tapi ia tak langsung ke Thanta. Ia mampir dulu ke rumah pamannya seorang pengikut tarekat al-Syadziliyah, Syekh Darwisy Khadr. Dari Khadr pula akhirnya Muhammad Abduh menimba ilmu, terutama yang berkaitan dengan tasawuf, untuk beberapa bulan. (Mohammad, 2006:226).

Setelah dirasa cukup, Muhammad Abduh lalu melanjutkan menimba ilmu di masjid al-Ahmad, tak lebih dari 3 bulan, ia sudah meninggalkan Thanta, menuju Kairo, guna menempuh pendidikannya di al-Azhar. Di sinipun Muhammad Abduh kembali kecewa, karena metode pembelajarannya sama dengan yang ia dapat di Thanta. Maka, ia pun mencari guru di luar al-Azhar. Dari sinilah Muhammad Abduh belajar ilmuilmu non agama yang tidak ia dapatkan di al-Azhar. Antara lain, filsafat, matematika dan logika. Ia mendapatkan ilmu-ilmu tersebut dari Syekh Hasan al-Tawil. (Mohammad, 2006:226).

Dunia pengabdiannya sebagai seorang pendidik ia rintis di al-Azhar. Gebrakan pembaruan pertamanya mengusulkan perubahan terhadap alAzhar. Ia yakin apabila al-Azhar diperbaiki, kondisi kaum muslimin akan membaik. Dan karena itu perlu diperbaiki teruatama dalam masalah perluasan kurikulum, mencakup ilmu-ilmu modern, sehingga al-Azhar dapat berdiri sejajar dengan universitas-universitas lain serta menjadi mercusuar dan pelita bagi kaum muslimin pada zaman modern. (Mohammad, 2006:226-227).

Muhammad Abduh sangat terpengaruh oleh pemikiran Jamaluddin al-Afghani, gurunya. Baginya, Jamaluddin al-Afghani adalah orang yang telah membukakan dunia islam di hadapannya, beserta problema yang dihadapinya di zaman modern. Jamaluddin al-Afghani bahkan telah mendorong dan mengarahkan Muhammad Abduh untuk membuat sebuah penerbitan yang menjadi media dakwah bagi kedua orang tersebut. Dari sini lahirlah majalah al-Urwah al-Wutsqa. (Mohammad, 2006:227).

Bekerjasama dengan gurunya, Jamaluddin al-Afghani, Muhammad Abduh mengelola majalah al-Urwah al-Wutsqa yang terbit di Paris. Muhammad Abduh termasuk tokoh pembaru islam yang banyak dibicarakan dan meninggalkan pengaruh yang kuat pada kaum muslimin. Muhammad Abduh adalah ulama yang menganjurkan dan membuka pintu ijtihad yang telah lama dikunci. Walaupun ide pembaruan Muhammad 
Abduh banyak menuai kritik, ia tetap konsisten menyebarkan pemikiranpemikiran pembaruan islam. Muhammad Abduh sangat tidak menyukai adanya ahli fikih dan ulama yang hanya menyibukkan diri dengan masalahmasalah furuiyah dan meninggalkan masalah utama umat. Muhammad Abduh juga dikenal sebagai tokoh yang gigih memerangi segala bentuk khurafat, ia mengajak umat agar memurnikan akidah mereka. (Mohammad, 2006:227).

Di masa Muhammad Abduh dan Jamaluddin al-Afghani hidup, umat islam mengalami kemunduran yang sangat memprihatinkan. Dunia islam tercabik-cabik oleh penjajah. Wilayah islam yang sebelumnya berada dalam naungan khilafag Utsmaniyah dikapling-kapling oleh bangsa eropa. Inggris menduduki Mesir, Sudan, Pakistan dan Bangladesh (India), Malaysia serta Brunei. Di samping kekalahan politik dan militer, pemikiran islam juga mengalami kemandegan. Di saat itulah muncul para tokoh islam yang mencoba membangkitkan kembali umat islam dalam berbagai sisi. Salah satu tokohnya adalah Jamaluddin al-Afghani. (Mohammad, 2006:227).

Kepada Jamaluddin al-Afghani, Muhammad Abduh belajar filsafat, ilmu kalam, ilmu pasti dan ilmu pengetahuan lain yang juga diperoleh di alAzhar. Pengajaran Jamaluddin al-Afghani dengan metode diskusi sangat menarik minat Muhammad Abduh. Sedangkan guru Muhammad Abduh yang lain, Syekh Darwisy, dengan tekun mengajarinya ilmu dan mengarahkannya pada kehidupan sufi. (Mohammad, 2006:227-228).

Selain itu, Muhammad Abduh pernah menjadi dosen di al-Azhar, Dar al-Ulum (kini Universitas Kairo) dan perguruan Khedevi. Ia juga pernah menjadi mufti Mesir dan menjabat sebagai hakim agung. Di bidang jurnalistik, selain mengoprasikan majalah al-Urwah al-Wutsqa, ia pernah menjadi pemimpun redaksi koran Waqai al-Mishriyyah, harian milik pemerintah yang mengupas persoalan-persoalan sosial, politik, agama dan negara. (Mohammad, 2006:228).

Menurut Muhammad Imarah dalam bukunya al-Amal al-Kamilah li al-Imam Muhammad Abduh, (Kairo), ide-ide pembaruan teologis yang disebarkan oleh Muhammad Abduh didasari oleh tiga hal yaitu; kebebasan manusia dalam memilih perbuatan, kepercayaan yang kuat terhadap sunnah Allah dan fungsi akal yang sangat dominan dalam menggunakan kebebasan. Pandangan Muhammad Abduh tentang perbuatan manusia bertolak dari satu deduksi, bahwa manusia adalah makhluk yang bebas dalam memilih perbuatannya. Namun kebebasan tersebut bukanlah kebebasan yang tanpa batas. Setidaknya ada dua ketentuan yang mendasari perbuatan manusia yaitu; pertama, manusia melakukan perbuatan dengan daya dan kemampuannya kedua, kekuasaan Allah adalah tempat kembali semua yang terjadi. (Mohammad, 2006:228). 
Muhammad Abduh memandang akal berperan penting dalam mencapai pengetahuan yang hakiki tentang iman. Akal dalam sistem teologi Muhammad Abduh bahkan memiliki kekuatan yang sangat tinggi. Berkat akal, orang dapat mengetahui adanya tuhan dan sifat-sifat-Nya, mengetahui adanya hidup di akhirat, mengetahui kewajiban-kewajiban terhadap tuhan, mengetahui kebaikan dan kejahatan serta mengetahui kewajiban membuat hukum. Namun menurutnya, akal masih membutuhkan wahyu sebagai petunjut hidup mereka. Sebab wahyu sesungguhnya memiliki dua fungsi utama, yakni menolong akal untuk mengetahui secara rinci mengenai kehidupan akhirat dan menguatkan akal agar mampu mendidik manusia untuk hidup secara damai dalam lingkungan sosialnya. (Mohammad, 2006:228).

Dalam bidang hukum, ada tiga prinsip utama pemikiran Muhammad Abduh, al-Quran sebagai sumber syariat, memerangi taklid dan berpegang kuat pada akal dalam memahami ayat-ayat al-Quran. Menurutnya, syariat itu ada dua macam, qathi (pasti) dan zhanni (tidak pasti). Hukum syariat jenis pertama wajib bagi setiap muslim mengetahui dan mengamalkan tanpa interpretasi, karena dia jelas tersebut dalam alQuran dan al-habits. Sedangkan hukum syariat jenis kedua datang dengan penetapan yang tidak pasti. (Mohammad, 2006:228-229).

Jenis hukum yang tidak pasti inilah yang menurut Muhammad Abduh menjadi lapangan ijtihad para mujtahid. Dengan demikian, mereka berbeda pendapat adalah sebuah kewajaran dan merupakan tabiat manusia. Keseragaman berpikir dalam semua hal adalah sesuatu yang tidak mungkin diwujudkan. Bencana akan timbul ketika pendapat-pendapat yang berbeda tersebut dijadikan tempat berhukum dengan taklid buta tanpa berani mengkritik dan mengajukan pendapat lain. Sekap terbaik yang harus diambil umat islam dalam menghadapi perbedaan pendapat adalah dengan kembali kepada sumber aslinya, al-Quran dan sunnah. Setiap orang yang memiliki ilmu yang mumpuni maka dia wajib berijtihad, sedang bagi orang awam, bertanya kepada orang yang ahli dalam agama adalah sebuah kewajiaban. (Mohammad, 2006:229).

Muhammad Abduh pernah menyarankan agar para ahli fikih membentuk tim yang bekerja untuk mengadakan penelitian tentang pendapat yang terkuat di antara pendapat-pendapat yang ada. Keputusan tim inilah yang kemudian dijadikan pegangan umat islam. Tim ahli fikih tersebut, selain bertugas memfilter hasil ijtihad ulama maupun mazhab masa lalu juga mengadakan reinterpretasi terhadapnya. Jadi menurut Muhammad Abduh, bermazhab berarti mencontoh metode beristinbath hukum. (Mohammad, 2006:229).

Dengan seluruh aktivitasnya ini, Muhammad Abduh bisa dikatakan telah mengangkat citra islam dan kualitas umatnya dari keterpurukan dan keterbelakangan. Ia adalah seorang mujtahid sekaligus mujahhid pada 
masanya. Diantara wawasan intelektualnya yang sampai saat ini masih dirasakan dan dikaji oleh umat adalah Risalah al-Tauhid. Sementara itu, kumpulan pidato, pemikiran dan ceramahnya telah ditulis oleh muridnya, Muhammad Rasyid Ridha, bertajuk Tafsir al-Manar. Pemikiran-pemikiran Muhammad Abduh tersebat di seluruh pelosok negeri. Di indonesia, pemikiran Muhammad Abduh banyak memengaruhi pola ormas islam, seperti Muhammadiyah. Dengan demikian, tidak berlebihan kalau kemudian Muhammad Abduh dikatakan sebagai figur seorang pembaru islam yang menggerakkan kebangkitan umat. (Mohammad, 2006:229-230).

Kehidupan Politik, Sosial dan Budaya

Muhammad Abduh bertemu dengan Al-Afghani untuk yang pertama kalinya, ketika ia dan mahasiswa lainnya berkunjung ke tempat penginapan Al-Afghani di dekat Al-Azhar. Dalam pertemuan itu AlAfghani mengajukan pertanyaan kepada mereka mengenai arti beberapa ayat Al-Qur'an, kemudian beliau berikan tafsirannya sendiri. Perjumpaan ini memberikan kesan yang baik dalam diri Muhammad Abduh (Nasution, 1996: 60-61).

Ketika Al-Afghani datang untuk menetap di mesir pada tahun 1871, Muhammad Abduh segera menjadi muridnya yang paling setia (Nasution, 1996: 61). Al-Afghani memberikan tekanan pada mata kuliah teologi dan filsafat, yang pada waktu itu di Al-Azhar dianggap dan disamakan dengan bid'ah. Sebelum berguru kepada Al-Afgani dan menekuni ilmu yang dianggap berbahaya itu, Muhammad Abduh minta nasihat kepada Syaikh Darwisy. Bukan saja guru sufy itu menghapus kecemasannya, bahkan menjamin bahwa filsafat (al-Hikmah) dan ilmu pengetahuan merupakan jalan yang paling selamat untuk mengenal dan menyembah Tuhan. Hanya orang-orang bodoh dan sembrono yang pada hakikatnya merupakan musuh-musuh Tuhan yang paling jahat, yang memandang mata kuliah ini sebagai bid'ah (Fakhry, 1987: 462).

Tahun 1877 Muhammad Abduh menyelesaikan pendidikannya di Al-Azhar dan mendapat gelar sebagai Alim. Ia mulai mengajar pertama di Al-Azhar kemudian di Dar Al-Ulum dan juga di rumahnya sendiri. Diantara buku-buku yang diajarkannya adalah buku akhlak karangan Ibnu Miskawaih, Muqaddimah Ibnu Khaldun dan sejarah kebudayaan Eropa karangan Guizot yang diterjemahkan Al-Tahtawi ke dalam bahasa Arab pada tahun 1857 (Nasution, 1996: 61). Kesempatan ini juga dimanfaatkan Muhammad Abduh untuk berbicara dan menulis masalah politik, sosial dan khususnya masalah pendidikan nasional, yang pada waktu itu kesadaran nasional di Mesir semakin meningkat. Tahun berikutnya (1879) Al-Afghani dan Muhammad Abduh diusir dari Mesir karena sikap politiknya yang dianggap terlalu keras. Pada saat yang sama Muhammad Abduh diberhentikan dari jabatan mengajarnya di Dar Al-Ulum. Namun tahun 1880 
ia segera diaktifkan kembali oleh perdana menteri serta diangkat menjadi salah satu editor, kemudian editor kepala surat kabar resmi pemerintah Mesir Al-Waqai'u Al-Mishriyyah. Dalam posisi ini ia menjadi sangat brpengaruh dalam membentuk pendapat umum (Rahnema, 1998: 38).

Muhammad abduh turut serta memainkan peran dalam revolusi Urabi Pasya, yaitu gerakan yang bermula dari usaha perwira-perwira militer Mesir yang berhasil mendobrak kontrol perwira-perwira Turki dan Sarkas yang menguasai Mesir. Selanjutnya gerakan di bawah pimpinan Urabi Pasya ini dapat menguasai pemerintahan, namun kekuasaan golongan nasionalis ini dianggap berbahaya dan mengancam kepentingan Inggris di Mesir. Akibatnya, untuk menjatuhkan Urabi Pasya, pada tahun 1882 Inggris membom Alexandaria dari laut. Dalam pertempuran ini kaum nasionalis dapat dikalahkan dan Mesir jatuh ke bawah kekuasaan Inggris. Sebagaimana pemimpin-pemimpin lainnya, Muhammad Abduh ditangkap dan dipenjarakan. Pada akhir tahun 1882 ia dibuang ke Beirut kemudian ke Paris pada tahun 1884 (Nasution, 1996: 61-62).

Muhammad Abduh memandang kemunduran bangsa-bangsa muslim sebagai akibat pemerintah otoriter yang yang ditimbulkan oleh kebodohanfaqih (ahli hukum Islam) dan kebodohan penguasa. Faqih dianggap bersalah karena tidak memahami politik dan bergantung kepada penguasa, sehigga penguasa tidak mempertanggungjawabkan kebijakannya. Sementara itu, penguasa bukan saja bodoh dalam hal memerintah dan menegakkan keadilan, bahkan mereka merusak faqih dan memanfaatkanfaqih untuk kepentingan mereka sendiri dengan cara memaksa faqihmengeluarkan fatwa untuk mempertahankan kebijakan pemerintah. Dalam keadaan demikian, hal yang terpenting bagi ummat adalah persatuan politik dan keadilan. Persatuan politik dan keadilan ini belum ada karena ketidakpedulian pemimpin. Segenap keburukan yang menimpa kaum muslimin adalah akibat dari kebodohan dan perpecahan pemimpin muslim yang menyandang gelar tinggi seperti pangeran dan sultan, yang hidup bergelimang dengan kemewahan, dan berupaya mencari perlindungan dari pemerintah asing yang bukan muslim untuk memperkuat dirinya dalam menghadapi rakyatnya sendiri. Pemimpin seperti ini menjarah kekayaan rakyat demi kesenangan pribadi, tidak menegakkan keadilan, tidak merujuk kepada kitab yang tepat atau tidak mengikuti sunnah, dan pemimpin seperti ini menjadi penyebab kerusakan akhlak ummat (Rahnema,1998:60-61).

Penguasa berhak untuk ditaati selama dia berpegang pada kebenaran Al-Qur'an dan Al-Sunnah, namun tidak ada ketaatan kepada orang yang durhaka terhadap Allah. Kaum muslimin berhak mengontrol dan terus menerus menilai penguasa, juga menuntut pertanggungjawabannya. Jika ia menyimpang dari jalan kebenaran, maka harus diganti. Ummat yang mengangkatnya, dan ummat punya otoritas atas 
dirinya. Khalifah atau sultan merupakan penguasa sipil yang wilayahnya bukanlah teokrasi. Tugas kaum muslimin adalah memberi nasihat kepada penguasa berdasar pada ajaran Islam seperti majelis syura. Siap atau tidaknya orang untuk menerapkan metode syura bukan ditentukan oleh terlatihnya mereka dalam meneliti, berpikir atau terlatihnya mereka dalam prinsip-prinsip berdebat, tetapi cukup dengan mengupayakan kebenaran dan adanya sistem yang memperhatikan kepentingan publik. Jangan berkhayal bahwa peraturan dan hukum yang adil bisa didasarkan pada model asing. Ada peraturan dan hukum yang cocok bagi sebagian orang, tetapi tidak cocok bagi sebagian yang lain. Oleh karena itu, mereka yang membuat peraturan dan hukum, janganlah mengakomodasi hukum asing, tetapi mereka harus memikirkan kondisi masyarakat dan watak khasnya. (Rahnema, 1998: 61-62).

\section{Tafsir Al-Manar}

Pada dasarnya penulisan Tafsir al-Manar bermula dari gagasan pemikiran dari tiga tokoh pembaharuan dalam Islam. Yaitu Jamaluddin alAfgani, Muhammad Abduh dan Muhammad Rasyid Ridha.

Muhammad Abduh telah merintis kebangkitan ilmiyah dan memberikan buahnya kepada murid-muridnya. Kebangkitan ini berpusat pada kesadaran islami, upaya pemahaman sosiologis islam dan pemecahan agama terhadap problematika kehidupan masa kini. Benih-benih kebangkitan itu sebenarnya dimulai dengan gerakan Jamaludin al-Afgani, yang kepadanya Muhammad Abduh berguru. Abduh memberikan mata kuliah tafsir di Universitas al-Azhar dan mendapat sambutan baik dari murid dan mahasiswanya. Dan Rasyid Ridha adalah murid paling tekun mempelajari mata kuliah tersebut, paling semangat dan mencatatnya dengan teliti. Maka dapatlah dikatakan bahwa ia adalah ahli waris tunggal bagi ilmu-ilmu Syaikh Muhammad Abduh. Buah nyata akal hal ini tampak jelas dalam tafsirya yang diberi nama Tafsir al-Quran al-Hakim, populer dengan nama Tafsir al-Manar, nisbah kepada majalah al-Manar yang diterbitkanya. (al-Qattan, 1992:511-512).

Tafsir al-Manar yang bernama tafsir al-Quran al-Hakim memperkenalkan dirinya sebagai, "kitab tafsir satu-satunya yang menghimpun riwayat-riwayat yang shahih dan pandangan akal yang tegas, yang menjelaskan hikmah-hikmah syari'at, serta sunnatullah (hukum Allah yang berlaku) terhadap manusia, dan menjelaskan fungsi Al-Quran sebagai petunjuk untuk seluruh manusia, disetiap waktu dan tempat. Tafsir ini disusun dengan redaksi yang mudah sambil berusaha menghindari istilahistilah ilmu dan teknis sehingga dapat di mengerti oleh orang awam tetap tidak dapat diabaikan oleh orang-orang khusus (cendekiawan). (Shihab, 1994:67). 
Adapun mengenai sistematika penulisan dalam tafsir alManar adalah penulisan secara susunan mushafi. Sebagaimana dapat dilihat bahwa dalam penafsiran al-Manar dimulai dari surat al-Fatihah dan diakhiri dengan al-Nas. Kemudian, dilanjutkan dengan penjelasan ayat per ayat yang ada, lalu dikaitkan dengan ayat qur'an lain beserta hadis yang terkait. Penjelasan yang ada dijabarkan dengan mengemukakan asbabun nuzul, dan keutmaan ayat-ayat tersebut.

\section{Metode Penafsiran Tafsir Al-Manar}

Secara global dapat dikemukakan bahwa Muhammad Abduh (guru Muhammad Rasyid Ridha) hidup dalam suatu masyarakat yang tengah disentuh oleh berbagai perkembangan yang ada di Eropa, dimana masyarakatnya sangat kaku, beku dan menutup pintu ijtihad, hal ini muncul karena adanya kecenderungan umat yang merasa cukup dengan produk ulama-ulam terdahulu, sehingga akal mereka beku (jumud), sementara di Eropa sendiri sedang berkembang biak pola kehidupan yang mendewakan akal.(Shihab, 1994:17). Sehingga muncul kelompok yang taqlid (mayoritas jumlahnya) dan kelompok tajdid (minoritas jumlahnya).

Berdasarkan kondisi di atas, Muhammad Abduh bermaksud dalam setiap penuangan pikirannya termasuk dalam kitab tafsirnya berkeinginan untuk selalu mengingatkan sekaligus menyadarkan umat untuk kembali kepada al-Qur'an dan Hadis. Seruan ini pula yang mengajak umat kepada fungsionalisasi akal dalam memahami al-Qur'an.

Dengan demikian suatu hukum ditetapkan berdasarkan suatu kondisi tertentu dan hendaknya kondisi tersebut dijelaskan. Bila kondisi berubah, ketetapan itu juga dapat berubah. Melalui terobosannya itu, Abduh berusaha mencapai tujuannya, yakni menjelaskan hakikat ajaran Islam yang murni, menurut pandangannya, serta menghubungkannya dengan kehidupan masa kini. Beberapa prinsip penafsiran yang menjadikan kerangka metodologi Tafsir al-Manarnya dapat dijelaskan sebagai berikut:

Pertama, penggunaan akal secara luas dalam menafsirkan al-Qur'an. Rasionalitas yang dijunjung tinggi oleh pengarang tafsir ini bertitik tolak dari asumsi bahwa ada masalah keagamaan yang tidak dapat diyakini, kecuali melalui pembuktian logika, sebagaimana diakuinya pula bahwa ada masalah keagamaan yang sulit dipahami akal, tetapi tidak bertentangan dengan akal. (Anwar, 2001:260)

Kedua, dikalangan ulama tafsir, Abduh dikenal sebagai face maker (peletak dasar) penafsiran yang bercorak Adabi-Ijtima'i (sastra dan budaya kemasyarakatan). Ayat-ayat yang ditafsirkannya selalu dihubungkan dengan keadaan masyarakat dalam usaha mendorong ke arah kemajuan dan pembangunan. (Anwar, 2001:260). 
Secara umum sebenarnya metode yang dipakai dalam Tafsir alManar tidak jauh berbeda dengan kitab-kitab tafsir yang lain yang menggunakan metode Tahlili.(Baidan, 2000:69). Namun karena penekanannya terhadap operasionalisasi petunjuk al-Quran dalam kehidupan umat Islam secara nyata, maka tafsir ini bisa dikatakan berbeda dengan tafsir-tafsir sebelumnya. Metode yang dirintis oleh Muhammad Abduh ini selanjutnya dikembangkan oleh murid-muridnya, seperti Muhammad Rasyid Ridha, al-Maraghi dan Amin Khuli. (Faiz, 2002:71)

Metode dan ciri-ciri pokok Muhammad Abduh dalam menafsirkan al-Quran adalah sebagai berikut:

a) Memandang setiap surah sebagai satu kesatuan ayat-ayat yang serasi

b) Ayat Al-Qur'an bersifat umum

c) Al-Quran adalah sumber Aqidah dan Hukum

d) Penggunaan akal secara luas dalam memahami ayat-ayat Al-Qur'an

e) Bersikap hati-hati terhadap hadits Nabi saw.

f) Bersikap hati-hati terhadap pendapat sahabat. (Shihab, 1994:70-92).

Hukum Poligami Menurut Muhammad Abduh

Menurut Muhammad Abduh intisari dari Q.S. al-Nisa 4:3 adalah bahwa Allah SWT memberikan solusi bagi orang yang takut memakan harta anak yatim yang dinikahi yaitu dengan menikahi empat orang wanita selain anak yatim. Dan jika takut tidak dapat berbuat adil maka sebaiknya menikahi seorang wanita saja. Karena hal tersebut lebih menjauhkan kita dari berbuat tidak adil dan zalim kepada kaum wanita. (Ridha, 1947:348). Dengan demikian sangat jelas bahwa syarat paling utama kebolehan seorang pria dapat berpoligami adalah mampu adil.

Islam mempersempit kebolehan berpoligami. Poligami hanya dapat dilakukan dalam keadaan darurat. Syarat paling utama seorang suami untuk berpoligami adalah dia harus benar-benar dapat berlaku adil. Muhammad Abduh mengatakan:

فمن تامل الايتين علم ان اباحة تعدد الزوجات في الاسلام امر مضيقة فيه اشد التضييق كانه ضرورة من الضرات التى تباح لماجها بشرط الثقة باقامة العدل والامن من الجور . (Ridha, 1943:349)

Maka barang siapa yang merenungkan kedua ayat tersebut akan mengetahui bahwa sesungguhnya kebolehan berpoligami di dalam islam adalah perkara yang yang sangat dipersempit seakan-akan poligami merupakan salah satu darurat dari kedaruratan-kedaruratan yang hanya dalam keadaan terpaksa dengan syarat dapat berbuat adil dan jauh dari sikap diskriminatif. 
Poligami dapat merusak keharmonisan keluarga seseorang. Poligami hanya menciptakan permusuhan di dalam keluarga. Itulah kerusakan yang terjadi pada zaman Muhammad Abduh. Sehingga menurut Muhammad Abduh, sudah tidak mungkin seseorang yang berpoligami dapat mendidik masyarakat.

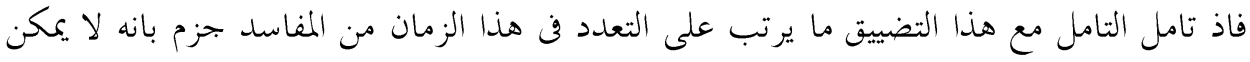

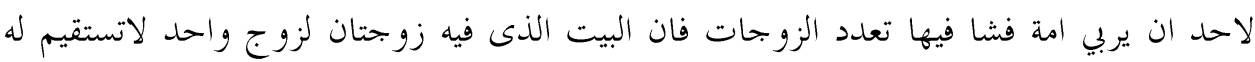

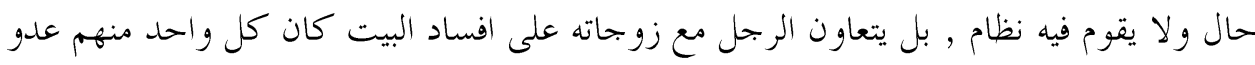

$$
\begin{aligned}
& \text { للاخر ثم يجئ الاولد بعضهم لبعض عدور فمفسدة تعدد الزوجات تنتقل من الافراد الى البيوت ومن لئن } \\
& \text { البيوت الم الامة. (Ridha, 1943:349) }
\end{aligned}
$$

Maka apabila para pemikir memikirkan perkara dipersempitnya poligami tidak mungkin dapat dilakukan pendidikan terhadap umat apabila masih terdapat praktik poligami. Maka sesungguhnya suatu rumah yang di dalamnya terdapat 2 orang isteri dan seorang suami maka akan sulit menegakan aturan di dalam rumah tersebut, bahkan yang terjadi adalah suami isteri (dalam rumah tersebut) saling mendukung terhadap hancurnya rumah tangga, setiap anggota keluarga yang satu menjadi musuh bagi anggota keluarga yang lainnya, lalu ketika muncul anak-anak (yang lahir dari tiap-tiap isteri) mereka akan saling memusuhi satu sama lain, maka kerusakan poligami berawal dari individu kemudian berefek kepada keluarga, lalu dari keluarga berefek kepada umat pada umumnya.

Terdapat perbedaan praktik poligami yang terjadi di zaman Muhammad Abduh dan Nabi Muhammad SAW. Praktik poligami yang terjadi pada awal perkembangan islam memiliki faidah-faidah diantaranya menyambungkan nasab (keturunan). Tidak muncul kerusakan poligami pada masa awal islam karena ajaran agama sudah benar-benar tertenam di dalam hati umat islam.

$$
\begin{aligned}
& \text { كان لتعدد في صدر الاسلام فو ائد اهمها صلة النسب والصهر الذى تقوى به العصيبة و لم يكن له }
\end{aligned}
$$

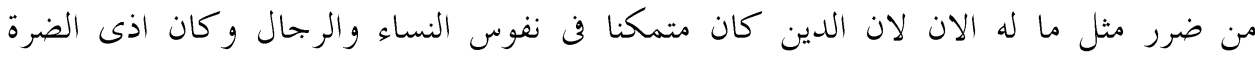

$$
\begin{aligned}
& \text { لايتجاوز ضرها. (Ridha, 1943:349) }
\end{aligned}
$$

Poligami pada masa awal islam memiliki faidah-faidah diantaranya yang terpenting adalah menyambungkan nasab (keturunan). Dan belum nampak pada masa tersebut kemadaratan-kemadaratan seperti yang terjadi pada masa kini karena ajaran agama benar-benar merasuk ke dalam jiwa perempuan dan laki-laki.

Pada zaman Muhammad Abduh, praktik poligami menimbulkan berbagai kemadaratan diantaranya adalah permusuhan antara anggota keluarga. Selain itu poligami juga melahirkan berbagai permasalahan 
lainnya diantaranya pencurian, zina, kebohongan, penghianatan, penipuan dan pembunuhan. Anak membunuh orang tuanya, orang tua membunuh anaknya, istri membunuh suaminya, suami membunuh istrinya, dan hal ini benar-benar terjadi pada zamannya.

Muhammad Abduh mengatakan:

$$
\begin{array}{r}
\text { العداوة اليوم فان الضغرر ينتقل من كل ضرة الى ولدها الى والدها الى سائر اقاربه فهي تغري بينهم } \\
\text { (Ridha, 1943:349) }
\end{array}
$$

Artinya: Adapun hari ini sesungguhnya kerusakan poligami berawal dari anak, kepada orang tua dan kepada seluruh kerabat keluarga yang terjadi diantara mereka adalah permusuhan dan kebencian.

Muhammad Abduh menyarankan kepada para ulama yang kondisi rusaknya praktik poligami yang terjadi di masyarakat untuk berpegang kepada kaidah meninggalkan kemafsadatan lebih utama daripada menarik kemaslahatan, karena tidak dapat dipungkiri bahwa agama turun untuk kemaslahatan bagi manusia. Dengan begitu maka wajib bagi para ulama untuk merubah hukum dan menetapkannya (menyesuaikannya) dengan keadaan yang ada pada masa kini. Hukum poligami adalah haram secara mutlak bagi yang takut tidak dapat berbuat adil.

$$
\begin{aligned}
& \text { اما والامر على ما نرى ونسمع فلا سبيل مع تربية الامة مع فشو تعلد الزوجات فيها فيجب على }
\end{aligned}
$$

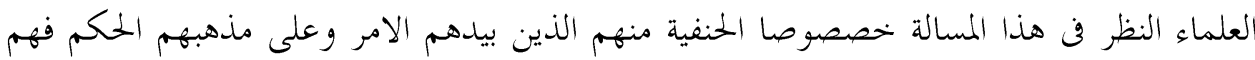

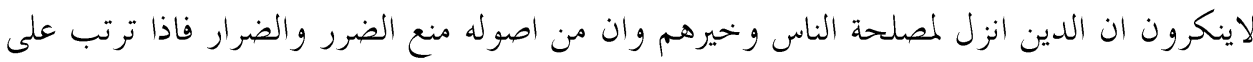

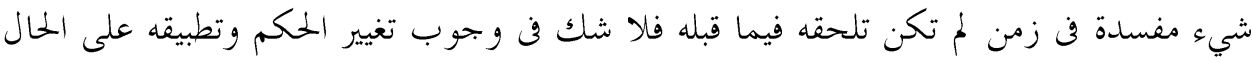

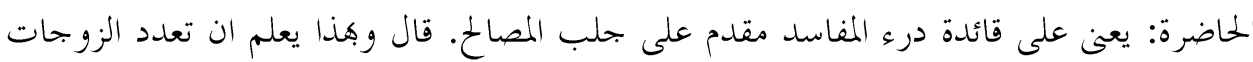

$$
\begin{aligned}
& \text { مررم قطعا عند الخوف من عدم العدل. (Ridha, 1943:349-350) }
\end{aligned}
$$

Adapun dengan kenyataan yang kita saksikan dan kita dengar yang mana tidak ada metode terhadap pendidikan umat dengan merajalelanya poligami, maka wajib bagi ulama untuk meninjau permasalahan ini khususnya bagi para pengikut imam hanafi yang memiliki kekuasaan dan hakimpun dari kalangan mereka, mereka tidak akan mengingkari bahwa sesungguhnya agama diturunkan untuk kemaslahatan dan kebaikan manusia dan tujuan mendasar agama adalah mencegah kerusakan, maka tidak diragukan lagi wajibnya merubah hukum dan menyesuaikan dengan zaman sekarang, yaitu berpegang kepada kaidah "mencegah kerusakan lebih utama daripada meraih kemaslahatan" dan dengan ini dapat diketahui bahwa poligami haram hukumnya bagi orang yang takut tidak dapat berbuat adil. 
Kemudian Rasyid Ridha menuturkan:

$$
\begin{aligned}
& \text { قال الاستاذ الامام ما قاله في التشنيع على التعدد الا لتنفير الذواقين من المصرين وامثاهم الذين } \\
& \text { يتزوجون كثيرا ويطلقون كثيرا لمض التنقل في اللنة والاغراق في طاعة الشهوة مع عدم التهذيب } \\
& \text { الدين والمدنى (Ridha, 1943:349-363) }
\end{aligned}
$$

Artinya: Muhammad Abduh menuturkan di dalam makalahnya mengenai poligami bahwa merupakan kebiasaan orang-orang Mesir dan yang seperti mereka adalah sering melakukan kawin cerai

Budaya buruk yang terjadi pada masa Muhammad Abduh adalah budaya kawin cerai yang dilakukan karena mengikuti keinginan hawa nafsu belaka. Kebiasaan ini menurut Muhammad Abduh telah menjadi budaya yang berkembang di masyarakat pada masa itu. Kebiasaan masyarakat ini, bertolak belakang dengan tujuan pernikahan. Karena salah satu tujuan dari adanya pernikahan adalah untuk membentuk keluarga yang kekal.

Menurut Muhammad Abduh monogami merupakan kebiasaan orang-orang yang memiliki peradaban. Sedikit sekali orang-orang yang beradab (maju) yang melakukan poligami. (Ridha, 1943:363). Muhammad Abduh mengatakan:

$$
\begin{aligned}
& \text { الا ان التهذيب الذى يعرف به الانسان قيمة الحياة الزوجية يمنع صاحب التعدد لغير ضرورة فهذه }
\end{aligned}
$$

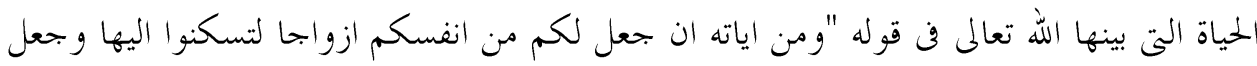

$$
\begin{aligned}
& \text { بينكم مودة ورحمة" فلما تحقق على كملها مع التعلد لاسيما اذا كان لغير عذر ولذلك يقل في } \\
& \text { المهزبين من ينجمع بين الزوجين }
\end{aligned}
$$

Menegakan kehidupan berumah tangga mencegah para praktisi poligami kecuali dalam keadaan darurat, hal inilah yang Allah jelaskan di dalam firman-Nya "dan diantara tanda-tanda kekuasaan kami adalah menjadikan bagi mu dari golongan mu isteri-isteri supaya kamu lebih cenderung kepadanya dan menjadikan diantara kamu kasih sayang"

Poligami merupakan penyimpangan tabiat dan penyimpangan kesempurnaan suatu keluarga, menghilangkan ketenangan diri, juga kasih dan sayang diantara anggota keluarga. Karena fitrahnya suatu pasangan adalah seorang suami dan seorang isteri. Muhammad Abduh mengatakan:

$$
\text { ان التعدد خحلاف الاصل وخلاف الكمال ويناف سكون النفس والمودة والرحمة التى هي اركن الحياة }
$$

الزوجية (Ridha, 1943:370) 
Sesungguhnya poligami merupakan penyimpangan dasar dan penyimpangan kesempurnaan (berumah tangga) dan dapat menghilangkan ketentraman jiwa juga kasih sayang yang mana hal tersebut merupakan bagian dari kehidupan rumah tangga.

Menurut Khoiruddin Nasution, Muhammad Abduh berpendapat bahwa poligami merupakan tindakan yang tidak boleh dan haram. Poligami hanya dibolehkan jika keadaan benar-benar memaksa seperti tidak dapat mengandung. Kebolehan poligami juga mensyaratkan kemampuan suami untk berlaku adil. Ini merupakan sesuatu yang sangat berat, seandainya manusia tetap bersikeras untuk berlaku adil, dengan melihat praktik poligami yang terjadi pada masa itu, tetap saja ia tidak akan mampu membagi kasih sayangnya secara adil (Khoiruddin Nasution, 1996: 100)

Dasar dari suatu kebahagiaan lahir batin adalah dengan monogami. Hanya saja poligami masih bisa dilakukan dalam keadaan isteri mandul. Itupun harus dengan persetujuan isteri. (Ridha, 1943:357). Dalam kondisi seorang isteri yang mandul, salah satu dari tujuan adanya pernikahan (menjaga keturunan) tidak akan tercapai. Kemandulan, bisa menyebabkan keharmonisan keluaga menjadi terganggu. Bahkan bisa menimbulkan masalah-masalah lain seperti zina. Sehingga dalam hal ini poligami menjadi rukhsoh.

Poligami juga bisa bernilai maslahat pada negara-negara yang kaum laki-lakinya lebih sedikit daripada perempuan, juga pada negara-negara yang rentang terjadi peperangan. (Ridha, 1943:357). Jika benar ada suatu negara yang jumlah perempuannya lebih banyak daripada kaum laki-laki, dan itu merupakan usia produktif, maka poligami bisa menjadi maslahat. Namun perlu diperhatikan pula apakah mental masyarakat di negara tersebut siap atau tidak.

Konsep Adil dalam Berpoligami Menurut Muhammad Abduh

Sebab turunnya (asbab al-nuzul) ayat ini adalah sebuah hadits yang diriwayatkan oleh Urwah bin Az-Zubair, ia pernah bertanya kepada

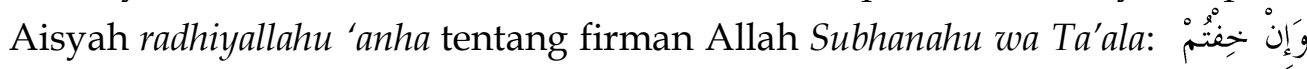

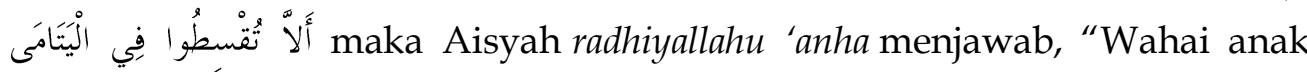
saudariku1. Perempuan yatim tersebut berada dalam asuhan walinya yang turut berserikat dalam harta walinya, dan si wali ini ternyata tertarik dengan kecantikan si yatim berikut hartanya. Maka si wali ingin menikahinya tanpa berlaku adil dalam pemberian maharnya sebagaimana mahar yang diberikannya kepada wanita lain yang ingin dinikahinya. Para wali pun dilarang menikahi perempuan-perempuan yatim terkecuali bila mereka mau berlaku adil terhadap perempuan-perempuan yatim serta memberinya mahar yang sesuai dengan yang biasa diberikan kepada wanita 
lain. Para wali kemudian diperintah untuk menikahi wanita-wanita lain yang mereka senangi." Urwah berkata, "Aisyah menyatakan, 'Setelah turunnya ayat ini, orang-orang meminta fatwa kepada Rasulullah Shallallahu 'alaihi wa sallam tentang perkara wanita, maka Allah Subhanahu wa Ta'ala menurunkan ayat:

$$
\text { ويستغتونك في النساء }
$$

Dan mereka meminta fatwa kepadamu tentang wanita. (Q.S. al-Nisa, 4: 127)

Aisyah radhiyallahu 'anha berkata, "Dan firman Allah Subhanahu wa Ta'ala dalam ayat yang lain:

$$
\text { وترغبون ان تنكحوهن }
$$

Sementara kalian ingin menikahi mereka (perempuan yatim). (Q.S. al-Nisa, 4: 127). (Ridha, 1947:344).

Berkenaan dengan adil Allah SWT berfirman:

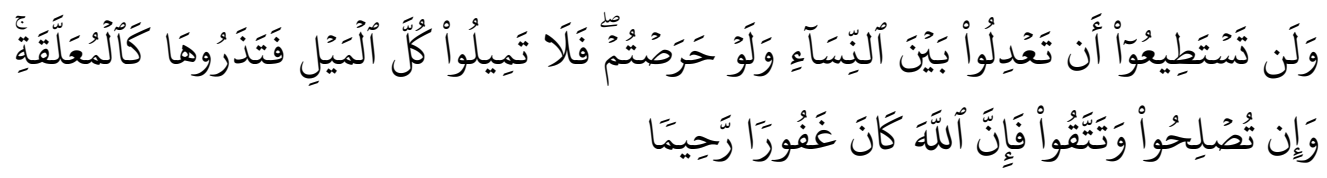

Dan kamu sekali-kali tidak akan dapat Berlaku adil di antara isteriisteri(mu), walaupun kamu sangat ingin berbuat demikian, karena itu janganlah kamu terlalu cenderung (kepada yang kamu cintai), sehingga kamu biarkan yang lain terkatung-katung. dan jika kamu Me ngadakan perbaikan dan memelihara diri (dari kecurangan), Maka Sesungguhnya Allah Maha Pengampun lagi Maha Penyayang. (Q.S. al-Nisa, 4:129).

Jika ayat ini digunakan untuk menjelaskan definisi adil Q.S. al-Nisa 4:3, maka tertutuplah kesempatan untuk berpoligami. Karena dalam ayat ini ditegaskan bahwa seorang pria benar-benar tidak akan dapat berlaku adil (bagi yang berpoligami) kepada isteri-isterinya.

Nabi Muhammad SAW pada akhir hayatnya pernah berkata bahwa ia lebih cenderung kepada Aisyah R.A daripada istri-itrinya yang lain. Meskipun demikian Nabi Muhammad SAW tidak pernah membedabedakan perlakuannya kepada isteri-isterinya dalam berbagai hal. (Ridha, 1943:348). Jika definisi adil dalam Q.S. al-Nisa 4:3 adalah masalah hati, maka Nabi Muhammad SAW pun tidak memenuhi syarat adil tersebut.

Memang frase pertama dari makna Q.S. al-Nisa 4:129 itu berbunyi, "Dan sekali-kali kamu tidak akan berbuat adil di antara para isterimu walaupun engkau menginginkan hal itu." Tetapi ketika kita lanjutkan membaca frase kedua ayat itu, akan berbunyi, "Maka janganlah kamu terlalu condong (terhadap yang kamu lebih cintai) sehingga kamu 
biarkan yang lain terkatung-katung...." Jelas bahwa mafhum mukhalafah (makna sebaliknya) dari frase kedua ayat di atas adalah, "Berbuat adillah engkau di antara mereka agar sebagian mereka tidak terkatung-katung," karena lawan dari "Jangan terlalu condng" adalah "berlaku lurus (berbuat adil)".

Jika demikian, tentunya makna "adil" pada frase pertama, bukan makna "adil" dalam frase kedua. Sebab kalau artinya sama tentu akan timbul makna yang kontradiktif, karena akan berbunyi begini," Dan kamu sekali-kali tidak akan bisa berkalu adil terhadap isteri-isterimu, walaupun kamu sangat ingin berbuat demikian, maka berlaku adillah." Sudah dijelaskan bahwa seseorang tidak akan bisa berlaku adil, mengapa malah disuruh berbuat adil lagi? Itu namanya membebankan seseorang dengan sesuatu yang tidak mampu dilakukan. Padahal Allah telah berfirman dalam surat al-Baqarah: "Allah tidak membebani seseorang dengan sesuatu yang tidak mampu ia laksanakan". Jadi adil dalam frase pertama berarti adil dalam urusan hati (seperti rasa cinta yang lebih kepada isteri yang lain), itu yang tidak mampu dilakukan oleh manusia manapun, karena urusan hati itu adalah urusan Allah. Rasulullah sendiri bersabda dalam hadits riwayat Imam Abu Dawud,"Ya Allah inilah pembagianku terhadap apa yang aku punyai (mampu melakukannya) dan janganlah mencelaku terhadap apa yang Engkau punya dan tidak ku punya."

Adapun makna "jangan berlaku condong" (berbuat adil) dalam frase Kedua berarti adil dalam muamalah (seperti dalam hal pemberian nafkah, giliran menginap, penyediaan fasilitas, pendidikan anak dsb), dan inilah yang bisa dilakukan oleh manusia, karena adil dalam masalah hati Rasulullah saja tidak mampu. Dengan demikian pemahaman ayat tersebut tidak akan kontradiktif. Karena tafsirannya akan berbunyi, "Engkau sekalikali tidak akan dapat berlaku adil dalam hal hati, karena hati adalah urusan Allah. Dia bisa saja menjadikanmu lebih mencintai salah seorang isterimu dari yang lain. Tetapi janganlah kecendrungan hati ini membuat engkau tidak berlaku adil dalam bermuamalah kepada mereka. Janganlah kecintaanmu yang lebih kepada salah satu isterimu membuat kamu tidak memperhatikan yang lain sehingga mereka terkatung-katung." Dengan demikian tidak akan terjadi makna yang kontradiktif.

Selain itu, makna adil dalam bermuamalah disini juga dikuatkan oleh Q.S. al-Nisa, 4:3 "Jika kamu takut tidak bisa berbuat adil, maka cukup (mengawini) satu orang saja." Makna ayat di atas mengindikasikan bahwa seseorang mungkin untuk berlaku adil terhadap isterinya. Karena ungkapan "in khiftum allaa ta'diluu" yang berarti "Jika kamu takut tidak bisa berbuat adil," mengandung arti ada kemungkinan seseorang untuk "tidak takut kalau ia tidak bisa berbuat adil, atau berani karena ia yakin bisa berbuat adil", dan ketika itu ia boleh menikah lebih dari satu. 
"Kemungkinan" di sini tentunya adalah kemungkinan berlaku adil dalam bermuamalah, karena adil dalam masalah hati sudah jelas tidak mungkin alias mustahil.

Muhammad Abduh pada tahun $1298 \mathrm{H}$ mengeluarkan fatwa yang cukup menghebohkan pada masanya. Fatwa tersebut dikutip secara panjang lebar oleh Ali Ahmad al-Jurjawi dalam bukunya yang sangat terkenal yaitu Hikmah al-Tasyri wa Falsafatuhu. Muhammad Abduh mengatakan bahwa syariat Nabi Muhammad saw memang membolehkan laki-laki mengawini empat perempuan sekaligus, jika laki-laki tersebut mengetahui kemampuan dirinya untuk berbuat adil. Jika tidak mampu berbuat adil, tidak dibolehkan beristeri lebih dari satu orang. Dalam hal ini, Muhammad Abduh mengutip "fain khiftum alla ta'dilu fawahidatan." Menurut Muhammad Abduh apabila seorang laki-laki tidak mampu memberikan hak-hak isterinya, rusaklah struktur rumah tangga dan kacaulah penghidupan keluarga. Padahal, tiang utama dalam mengatur kehidupan rumah tangga adalah adanya kesatuan dan saling menyayangi antar anggora keluarga. (Hasyim, 2001: 161)

Dari kutipan al-Jurjawi atas fatwa Muhammad Abduh tersebut, dapat dilihat bahwa Muhammad Abduh sangat menekankan pada keadilan yang kualitatif dan hakiki, seperti perasaan sayang, cinta dan kasih, yang semuanya tidak dapat diukur dengan angka-angka. Hal ini sesuai dengan makna yang digunakan oleh al-Quran, yaitu 'adalah, yang memang memiliki makna yang kualitatif. Adapun keadilan yang dikemuakakan oleh para ahli fiqih cenderung bersifat kuantitatif, yang sebenarnya lebih tepat untuk kata qisthun. Keadilan kuantitatif ini bersifat rentan karena sifatnya mudah berubah. Keadilan kuantitatif tersebut tampat dalam aturan-aturan fiqih mengenai poligami, misalnya tentang pembagian rezeki secara merata di antara isteri-isteri yang dikawini, pembagian jatah hari (giliran) dan sebagainya. Para ahli fiqih tidak memperhatikan aspek-aspek kualitatif yang justru sangat menentukan misalnya rasa cinta, tidak pilih kasih, memihak dan sebagainya. Padahal keadilan kualitatif ini seharusnya menjadi prioritas utama. Orang yang bisa mencapat keadilan kuantitatif belum tentu bisa mencapat kualitatif. (Hasyim, 2001:161-162).

\section{KESIMPULAN}

Dari pembahasan tersebut penyusun dapat menyimpulkan beberapa hal sebagai berikut: (1) Menurut Muhammad Abduh hukum poligami adalah haram bagi orang yang takut dapat berbuat adil. Pendapatnya ini didasarkan kepada keadaan zaman yang terjadi pada masanya terutama ketika ia menjadi hakim. Banyak sekali terjadi kerusakan-kerusakan yang ditimbulkan oleh praktik poligami. (2) Menurut Muhammad Abduh 
keadilan yang dimaksud adalah keadilan kualitatif. Keadilan kualitatif ini diantaranya adalah rasa cinta, kasih dan sayang.

\section{DAFTAR PUSTAKA}

Abu Lu'bah, Abdurrahim Faris. (2005) Syawa ib al-Tafsir fi al-Qarni alRabi' 'Asyara al-Hijri, (Disertasi Doktor), (Beirut: Jamiah Beirut alIslamiyah Kulliyah Asy-Syariah li Dar al-Fatwa Lubnan Idarat alDirasat al-Ulya.

Al-'Attar, Abdul Nasir Taufiq. (1976). Polygami Ditinjau dari Segi Agama, Sosial, dan Perundang-Undangan. Diterjemahkan oleh Chadidjah Nasution. Bulan Bintang, Jakarta.

Al-Famawiy, Abdul Hay. (1977) Al-Bidayah fi Al-Tafsir Al-Maudhu'iy, AlHadharah Al-Arabiyah, Kairo.

Al-Farmawi, Abdul Hayy. (2002). Metode Tafsir Maudhu'I dan Cara Penerapannya. Diterjemahkan oleh Rosihon Anwar. Pustaka Setia, Bandung.

Alhamdani, H.S.A. (1985). Risalah Nikah. Diterjemahkan oleh Agus Salim. Pustaka Amani, Jakarta.

Al-Husaini, Abi Bakar bin Muhammad. (t.t). Kifayatul Akhyar. Maktabah alHidayah, Surabaya.

Al-Kurdi, Ahmad Al-Hajj. (t.t.). Hukum-hukum Wanita dalam Fiqih Islam. Diterjemahkan oleh Moh. Zuhri dan Ahmad Qarib. Dina Utama, Semarang.

Al-Qotthon, Manna' Kholil. (t.t.). Mabahits Fi Ulumil Qur'an. Maktabah Wahbah, Kairo.

Al-Tsabt, Khâlid bin Utsmân (1997) Qowâ'id al-Tafsîr Jam'an wa Dirâsasatan. Dâr ibn 'Affân, Arab Saudi

Al-Zarqânî, Muhammad 'Abd al-Azhîm. (1995) Manâhil al-'Irfân fî̀ 'Ulûm alQur'ân. Dâr Ihya' al-Turats al-Arabiy, Beirut.

Anwar, Rosihon. (2009). Pengantar Ulumul Quran. Pustaka Setia, Bandung.

Ash Shidieqy, M. Hasbi. (1954) Sejarah dan Pengantar Ilmu al-Quran/tafsir. Bulan Bintang, Jakarta.

Gusmian, Islah. (2003) Khazanah Tafsir Indonesia (dari Hermeneutika hingga Ideologi. Teraju, Jakarta.

M. Nashirudin, Sidik Hasan. (2009) Poros-poros Ilahiyah Perempuan Dalam Lipatan Pemikiran Muslim. Jaring Pena, Surabaya. 
Mohammad, Herry dkk. (2006) Tokoh-tokoh Islam yang Berpengaruh Abab 20. Gema Insani, Jakarta.

Mursalin, Supardi. (2007) "Menolak Poligami, Studi tentang Undang-undang Perkawinan dan Hukum Islam". Pustaka Pelajar, Yogyakarta.

Nasution, Khoiruddin. (1996) Riba dan Poligami sebuah studi atas Pemikiran Muhammad Abduh. pustaka Pelajar, Yogyakarta.

Nawawi, Rif'at Syauqi dan M. Ali Hasan. (1992) Pengantar Ilmu Tafsir. Badr al- al-Zarkasyî, Dîn Muhammad ibn 'Abdullâh ibn Bahâdir. (1957) alBurhân fì 'Ulûm al-Qữ ân, (di-tahqqîq oleh Muhammad Abû al-Fadhl Ibrâhîm) Dâr al-Ma'rifah, Beirut.

Nurmila, Nina. (2009). Women, Islam, and Everyday Life: Renegotiating Polygamy in Indonesia. Routledge, New York.

Philips, Abu Ameenah Bilal dan Jameelah Jones. (2005). Polygamy in Islam. International Islamic Publishing House, Riyadh.

Qutub, Sayyid (1961) Tafsir fi dhilali al-Qur'an. Dar al-Kutub Al-Ilmiyah.

Ridha, Muhammad Rasyid. (1994). Panggilan Islam Terhadap Wanita.Penerbit Pustaka, Bandung

Sahran, Sohari 2010 "Fikih Munakahat" Rajawali Pers, Jaarta.

Shihab, Quraish. (1999) Sejarah dan Ulum al-Qur'an. Pustaka Firdaus, Jakarta.

Subana. (2001) Dasar-dasar Penelitian Ilmiah. CV. Pustaka Setia, Bandung. 